\title{
MANUFACTURE AND UTILIZATION OF BANANA FLOUR
}

BY

Sangarangae Dona Dhanoja Sandanayaka

Thesis submitted to the University of Sri Jayawardenapura for the award of the degree of Masters of Food Science and Technology on 2006 


\section{DECLARATION}

"The work described in this thesis was carried out by me under the supervision of Dr.K.K.D.S.Ranaweera Head, Dept. of Food Science \& Technology, Faculty of applied sciences, University of Sri Jayawardenapura, and Mr. M.A. Jagath Wansapala, The Lecturer, Dept. of Food Science \& Technology, Faculty of applied sciences, University of Sri Jayawardenapura and a report on this has not been submitted in whole or in part to any university or any other institution for another degree/diploma".

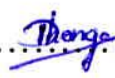

S.D.D. Sandanayaka 
We certify that the above statement made by the candidate is true and that this thesis is suitable for submission to the university for the purpose of evaluation.

Date

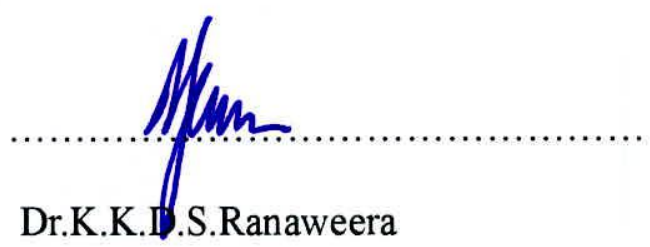

Head, Dept. of Food Science \& Technology,

Faculty of applied sciences,

University of Sri Jayawardenapura

Sri Lanka

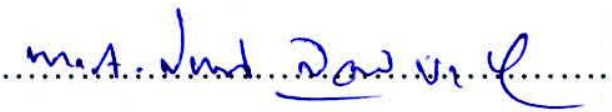

Mr. M.A. Jagath Wansapala

Lecturer

Dept. of Food Science \& Technology

Faculty of applied sciences,

University of Sri Jayawardenapura

Sri Lanka 
I dedicate this thesis

To my parents 


\section{TABLE OF CONTENTS}

Content

Page

TABLE OF CONTENTS

LIST OF TABLES iv

LIST OF FIGURES — vi

LIST OF PLATES vii

ACKNOWLEDGEMENT viii

ABSTRACT

CHAPTER 1

ix

INTRODUCTION

1.1 General introduction 1

1.1.1 Banana 1

1.2 The significance of using banana flour as starch source 2

1.3 Aim of this investigation 3

\section{CHAPTER 2}

2 LITERATURE REVIEW

2.1 General information /Banana 4

2.2 Uses of banana 9

$\begin{array}{lll}2.3 & \text { Nutritional value of banana } & 12\end{array}$

$\begin{array}{lll}2.4 & \text { Medicinal value } & 14\end{array}$

$\begin{array}{ll}2.5 & \text { Changes in ripening of fruit } \\ \end{array}$

$\begin{array}{lll}2.6 & \text { Browning of banana } & 17\end{array}$

$\begin{array}{lll}2.7 & \text { Starch introduction } & 18\end{array}$ 
$\begin{array}{llr}2.7 .1 & \text { Composition } & 18\end{array}$

$\begin{array}{ll}\text { 2.7.2 The starch granule } & 20\end{array}$

$\begin{array}{lll}\text { 2.7.3 Properties of starch } & 22\end{array}$

2.7.4 Some studies on banana Starch $\quad 24$

2.8 General information on manufacture of bread 25

$\begin{array}{lll}2.9 & \text { General drying methods } & 27\end{array}$

CHAPTER 3

3 EXPERIMENTAL

3.1 Preparation of banana flour $\quad 30$

3.2 Yield of banana flour and properties of flour 36

3.3 Moisture determination 36

$\begin{array}{lll}3.4 & \text { Determination of fat } & 37\end{array}$

3.5 Determination of crude protein /Kjeldhal method 38

3.6 Determination of fiber $\quad 40$

3.7 Determination of ash 42

3.8 Determination of reducing sugar/of total sugar/starch 43

3.9 Incorporate banana flour in to bread formulae 43

3.10 Determination of the volume of loaf 46

3.11 Incorporate banana flour in to other bakery products-cakes 47

3.12 Investigate possibility of using banana flour in Custard formulae 48

3.13 Sensory evaluation of (bread, cake and custard pudding) 50 


\section{CHAPTER 4}

\section{RESULTS \& DISCUSSION}

4.1 Best method to prepare banana flour 53

4.2 Yield of flour and properties of flour 53

4.3 Proximate composition of banana flour $\quad 57$

$\begin{array}{lll}\text { 4.3.1 } & \text { Moisture content } & 57\end{array}$

$\begin{array}{lll}\text { 4.3.2 Fat content } & 58\end{array}$

$\begin{array}{llr}\text { 4.3.3 Protein content } & 58\end{array}$

$\begin{array}{llr}\text { 4.3.4 Fiber content } & 59\end{array}$

$\begin{array}{lll}\text { 4.3.5 Ash content } & 59\end{array}$

4.3.6 Reducing sugar content/Total sugar content/Starch content 60

4.4 Manufacture of bread $\quad 62$

4.5 Manufacture of cake $\quad 66$

4.6 Preparation of custard with banana flour $\quad 68$

$\begin{array}{lll}4.7 & \text { Sensory analysis } & 70\end{array}$

\section{CHAPTER 5}

$\begin{array}{lll}5 & \text { CONCLUTIONS } & 72\end{array}$

$\begin{array}{lll}6 & \text { REFERENCES } & 73\end{array}$

$\begin{array}{lll}7 & \text { APPENDIX } & 76\end{array}$ 


\section{LIST OF TABLES}

Table

Page

2.1 Composition of Fresh banana fruit $\quad 12$

$\begin{array}{ll}2.2 \text { Composition of banana flour } & 13\end{array}$

$\begin{array}{ll}2.3 \text { amylose and amylopectin of various starches } & 19\end{array}$

2.4 Characteristics of unmodified starches 23

2.5 Thermal analysis of starches isolated from non-conventional sources 24

3.1 Formulations for banana based bread 43

3.2 Formulations for banana based bread $\quad 44$

4.1 Yields of flour of different varieties and $\mathrm{pH}$ value of each 53

4.2 Moisture content of banana flour $\quad 57$

4.3 Fat content of banana flour $\quad 58$

4.4 Protein content of banana flour $\quad 58$

4.5 Fiber content of banana flour $\quad 59$

4.6 Ash content of banana flour $\quad 59$

4.7 Reducing sugar content/total sugar content/starch content of banana flour $\quad 60$

4.8 Proximate composition of banana flour - Embon 60

4.9 Quality evaluation of bread $\quad 62$

4.10 Quality evaluation of bread 63

$\begin{array}{ll}4.11 \text { Loaf volume variation } & 64\end{array}$

$\begin{array}{ll}\text { 4.12 The nature of resulted custard } & 68\end{array}$

4.13 Comparison of tabular and calculated values for each attribute $\quad 70$

4.14 Comparison of tabular and calculated values for each attribute $\quad 70$ 


\section{LIST OF FIGURES}

$\begin{array}{lll}\text { Figure } & \text { Page }\end{array}$

2.1 Representative partial structure of amylose and amylopectin molecules $\quad 18$

2.2 Diagram of radial separation of layers in a typical starch granule and $\quad 21$ proposed microstructure of starch granule depicting micellar and amorphous regions

2.3 Behaviors of starch molecules in solution 22

3.1 Flow diagram of preparation of banana flour 33

3.2 Flow diagram of preparation of banana flour $\quad 34$

3.3 Flow diagram of preparation of banana flour $\quad 35$

3.4 Flow diagram of manufacturing bread 45 


\section{LIST OF PLATES}

Plate

Page

3.1 Embon (AAA)

3.2 Prepared samples of cake for sensory evaluation 52

4.1 Banana starch granules (Embon) 55

4.2 Banana starch granules (Alukehel)

4.3 Banana starch granules (Kolikuttu) 56

4.4 Banana starch granules (Seeinkehel) 56

4.5 Banana starch granules (Anamalu) 56

$\begin{array}{ll}4.6 \text { Trial Breads }(01) & 62\end{array}$

$\begin{array}{ll}\text { 4.7 Steps in manufacturing process } & 65\end{array}$

$\begin{array}{ll}4.8 \text { Trial breads }(02) & 65\end{array}$

$\begin{array}{ll}4.9 \text { Cakes prepared } & 67\end{array}$

4.10 Caramel custard pudding $\quad 69$ 


\section{ACKNOWLEDGEMENTS}

I wish to express my sincere thank and heart felt gratitude to my supervisors Dr. K.S.D.D.Ranaweera, Head, Department of Food Science \& Technology, Faculty of applied sciences, University of Sri Jayawardenapura and Mr. M.A. Jagath Wansapala, lecturer, Department of Food Science \& Technology, Faculty of applied sciences, University of Sri Jayawardenapura.

My sincere thank also extended to Prof. Arthur Bamunuarachchi for his valuable advices and guidance given to make this study success.

At the same time, I sincerely acknowledge, Mrs. Rupika Perera for realistic co-operation rendered and also to Mr. Sisira Weerasingha for the technical assistance given to me throughout my research project. Also, I would like to cordially remember assistance given by other lab staff members. 


\title{
MANUFACTURE AND UTILIZATION OF BANANA FLOUR
}

\section{By}

\section{S.D.D. Sandanayaka}

\begin{abstract}
The purpose of the study was to manufacture banana flour while keeping the nutritional value and determine the effects on appearance, tenderness, moisture, and eating quality of banana flour incorporated foods such as banana bread, banana custard and banana cake. The amount of starch, protein, total fat, and the total fibre in the banana flour were determined, and the contents of sugar and reducing sugar were also assayed.

Banana flour was prepared from five banana varieties, namely Embon, Alukehel, Kolikuttu, Seenikehel and Anamalu. Embon (AAA) was evaluated for its physical and chemical characteristics. The yields of flour averaged $20.7 \%$ and $\mathrm{pH}$ range was 5.1 to 5.0 . The average chemical composition ( $\%$ dry matter) of the flour was as follows: moisture $10.8 \pm 1.4$, crude protein $1.1 \pm 0.07$, total fat $1.0 \pm 0.2$, fiber $2.0 \pm 0.1$ and ash $2.6 \pm 1.4$. Carbohydrate composition indicated the flour to contain $3.2 \pm 0.2 \%$ reducing sugars, total sugar $3.3 \pm 0.07 \%$ and $60.2 \pm \%$ starch. Estimated values for available carbohydrate is $82.8 \%$ and caloric value of flour is $344.5 \mathrm{Kcal} / 100 \mathrm{~g}$. The overall results are suggestive of the potential of green bananas as a source of flour.

The banana flour was substituted for $20 \%$ of the wheat flour in a master mix. The bread was tested for taste, colour, odour and texture or mouth feel of the treatment products were compared to products made using the original wheat flour. Fifteen untrained panelists evaluated the banana bread. Results for the banana bread indicate that there was no
\end{abstract}


significant difference in taste, Colour, odour, and texture except overall acceptability for the mixed samples, when compared to the control sample. The study indicates that banana flour can be incorporated successfully into a master mix of bread with further improvements.

The banana flour was substituted for $20 \%$ of the wheat flour in a master mix for cake and banana custard, prepared replacing egg by banana flour. There is no significant difference in the taste, odour, texture and overall acceptability of the banana custard and banana cake when compared to their reference products. Banana custard can be introduced as vegetarian custard. Products made with banana flour are acceptable. 


\section{CHAPTER 1 \\ INTRODUCTION}

\subsection{General Introduction}

\subsubsection{Banana}

A banana plant is an herb in the genus Musa, which because of its size and structure, is often mistaken for a tree. Banana belongs to the family Musaceae. Banana consists of desert varieties, which could be eaten without cooking and cooking varieties generally referred as plantains. The edible cultivars derived from two wild species Musa acuminata (AA) and Musa balbisiana (BB). A-genome provides character of the desert fruit and B-genome provides starchy characters of the cooking variety. The plantain or cooking banana is classified as Musa x paradisiaca. The Manila hemp or abaca is classified as Musa textilis.

Globally, bananas rank fourth after rice, wheat and maize in human consumption. They are grown in 130 countries worldwide, more than for any other fruit crop. Bananas are native to tropical Southeastern Asia. They are at the same time a major staple commodity, together with rice, wheat and maize, and a fundamental export commodity. Bananas are grown extensively in tropical and subtropical regions and are an important food crop. Although the composition of banana fruit has been defined, comparatively little work has been carried out on the flour (Luis, 1998). Banana is a climacteric fruit and in Sri Lanka is consumed when the fruit is ripe. For this reason many fruits are lost during commercialization due to deficient post harvest handle.

Some local varieties of banana are of small sized fruit. Due to low commercial acceptance for export, it can be considered as a possible resource for industrial 